\title{
Biodiversity-ecosystem function relationship in microphytobenthic diatoms of the Westerschelde estuary
}

\author{
R. M. Forster ${ }^{1,3}$, V. Créach ${ }^{1,3, *}$, K. Sabbe ${ }^{2}$, W. Vyverman ${ }^{2}$, L. J. Stal ${ }^{1}$ \\ ${ }^{1}$ Netherlands Institute of Ecology (KNAW-NIOO-CEME), PO Box 140, 4400 AC Yerseke, The Netherlands \\ ${ }^{2}$ Laboratory of Protistology and Aquatic Ecology, Department of Biology, Ghent University, Krijgslaan 281-S8, \\ 9000 Ghent, Belgium
}

${ }^{3}$ Present address: Centre for Environment, Fisheries and Aquaculture Science (CEFAS), Pakefield Road, Lowestoft, Suffolk NR33 OHT, UK

\begin{abstract}
Studies investigating the role of species diversity in sustaining key ecosystem processes, such as primary production, have until now mainly focused on terrestrial plant and soil communities. Although the relationship remains controversial, most evidence suggests that decreases in species diversity adversely affect ecosystem functions. It is unclear, however, whether conclusions derived from terrestrial systems can be readily transferred to aquatic systems. In the present study, the relationship between the diversity of intertidal benthic diatom biofilms and their estimated net primary production $\left(P_{\mathrm{n}}\right)$ in the macrotidal Westerschelde estuary was investigated. Diversity measures were calculated on the basis of relative cell counts down to species level. Biomass was estimated as chlorophyll $a$, and $P_{\mathrm{n}}$ was modelled using a vertically resolved primary production model on the basis of measurements of photosynthetic activity, biomass and abiotic parameters. Species composition of benthic diatoms differed significantly between sites along the salinity gradient of the estuary. As epipelic species were strongly correlated with photosynthetically active surface biofilm biomass and, hence, also with primary productivity, we focused on the diversity of this functional group. The results indicate that (1) biomass appears to be inversely related to the diversity of the biofilms (Periods of low biomass did not show low diversity [as reported in phytoplankton], possibly because these events were driven by grazing pressure and not by nutrient stress) and (2) relationships between diversity (species richness and Shannon index) and $P_{\mathrm{n}}$ appeared to be site specific, with either a significant positive or a unimodal relationship between both parameters.
\end{abstract}

KEY WORDS: Benthic diatoms $\cdot$ Biodiversity $\cdot$ Biomass $\cdot$ Net primary production

\section{INTRODUCTION}

Coastal zones and wetlands are among the most productive natural systems in the world, with high economic and ecological value (Woodward \& Wui 2001). Although spatially resolved assessments of coastal ecosystem metabolism are still at an early stage (Gazeau et al. 2004), it is clear that estuaries are important sites of biogeochemical activity (Heip et al. 1995). Intertidal and shallow subtidal sediments of estuaries are areas where particularly high rates of elemental cycling occur (Middelburg et al. 2005), due to the presence of key functional groups such as denitrifying bac- teria, suspension-feeding molluscs, bioturbating polychaetes, as well as macrophyte and microalgal primary producers. In order to understand how future changes in external factors such as salinity, nutrients and mean sea level will impact coastal systems, the responses of these key groups of organisms must be analysed (Heip et al. 2003). The relationship between the number of species or functional groups and the function of the ecosystem as a whole should be clarified, so that any adverse results of species loss can be predicted.

To date, research on the role of species diversity in sustaining ecosystem processes has focused primarily on terrestrial plant and soil communities (Waide et al. 
1999, Loreau 2000). For these systems, the hypothesis of a direct relationship between species diversity and productivity is based on the assumption that interspecific differences in the use of resources by plants enhance their use of the available resources, e.g. in terrestrial experiments with grasses (Wardle et al. 2000).

Similar effects have been observed in marine benthic ecosystems, but no general conclusions can be drawn, as experimental designs have often been performed on small-scale assemblages with low numbers of species (reviewed by Covich et al. 2004).

Estuaries are unusual in that high biogeochemical rates are accounted for by relatively low taxonomic diversity and low numbers of species (Costanza et al. 1993). This is due to physical stress: the tidally driven variations in salinity and water level that characterise most estuarine systems exert a strong selectional pressure. Only a limited number of species have adapted to changing salinity via, for example, the use of osmoregulatory systems (Webb et al. 1997). In low-diversity ecosystems, there is potentially a greater chance that certain species or groups of species may be critical to the maintenance of function (i.e. there is a lower level of redundancy).

In the case of estuarine sediments, a considerable amount of biological activity is associated with a thin layer of microscopic algae that inhabit the sediment surface (Cahoon 1999). The algal layer is important in a number of ecosystem processes. Microphytobenthos are an important source of new organic carbon (Underwood \& Kromkamp 1999), including the production of fatty acids, which are essential for higher trophic levels (Dunstan et al. 1994). The microphytobenthic layer can also control the rate and direction of inorganic nutrient exchange between benthic and pelagic compartments
(Sundbäck et al. 2000), and the physical presence of a smooth, overlapping layer of diatom cells and excreted polymeric substances can increase erosion resistance (Tolhurst et al. 2003). Recent investigations have shown considerable spatial separation (Underwood et al. 1998) and niche separation among different species of benthic diatoms (Underwood \& Provot 2000), but there is as yet no information on the extent to which overall biofilm metabolism corresponds to species richness.

The aims of this study were to evaluate the relationship between the diversity of benthic diatom species along the natural salinity gradient of a macrotidal estuary and their most important ecosystem function, net primary production ( $P_{\mathrm{n}}$, Gattuso et al. 1998). It is difficult to manipulate species richness in artificial microbial assemblages, as some species are uncultivable or disappear when natural sediment samples are brought into the laboratory (Defew et al. 2002); therefore, we compared direct measurements of biomass and primary productivity with diversity indices of natural biofilms sampled in the field.

\section{MATERIALS AND METHODS}

Site description. By sampling at points along a natural salinity gradient, at different shore heights and at all times of year, the aim was to capture the maximum variation in estuarine environmental conditions. It was assumed that this would drive ecological diversity in microphytobenthic communities. Environmental conditions, microphytobenthic biomass, photosynthetic activity and biodiversity were measured repeatedly at 3 intertidal locations, Appelzak (A), Biezelingsche Ham (B) and Paulina polder (P), along the natural

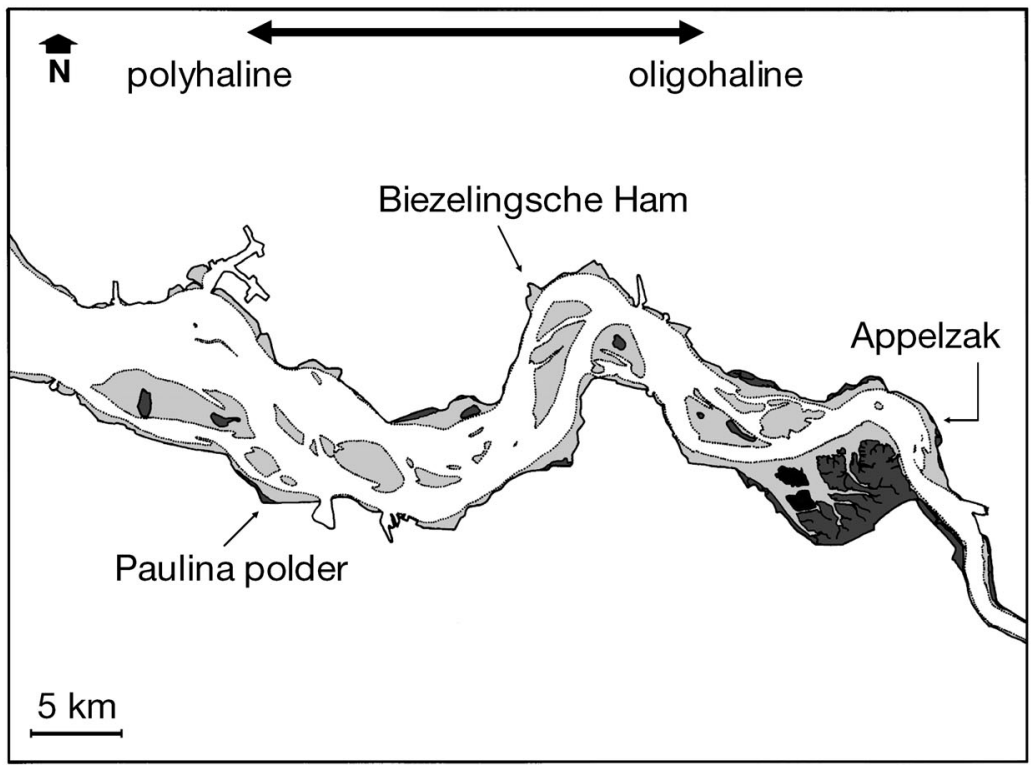

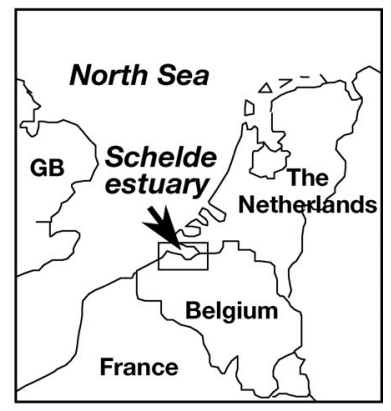

Fig. 1. Westerschelde estuary showing locations of the sampling sites: Appelzak (A), Biezelingsche Ham (B), Paulina polder $(\mathrm{P})$ 
salinity gradient of the Westerschelde estuary in the south-west of the Netherlands (Fig. 1). At each location, high-shore (A1, B1, P1) and mid-shore (A2, B2, P2) stations were selected on the exposed mudflats. Positions were determined by GPS (global positioning system), and each site was visited 8 times during the period from May 2002 to September 2003. Site visits were made during daytime low tides, within the time period from 10:00 to 14:00 h. Shore heights of the stations relative to lowest and highest tidal levels were determined by reference to a digital elevation model of the estuary, and were confirmed by direct observation of the timing of emersion and immersion periods. The key physical and biological parameters for each site are listed in Table 1.

Sampling. Surface sediment samples (upper $2 \mathrm{~mm}$ ) were taken with a contact corer (Ford \& Honeywill 2002). This layer includes all photosynthetically active cells, as well as the bulk of sediment chlorophyll, which is highly concentrated at the surface at these locations. On each sampling occasion, 5 replicate samples were taken within $5 \mathrm{~m}$ of the GPS location. Individual cores were used for determination of microphytobenthic biomass and water content. Pooled samples $(n=5)$ were used for grain size analysis and diatom species composition, as these parameters did not differ at this spatial scale. In addition, 4 fresh core samples of $4.5 \mathrm{~cm}$ diameter and $1 \mathrm{~mm}$ depth were pooled and transported to the laboratory for photosynthesis assays. Sediment surface temperatures (SST) were measured with an electrical thermometer during each of the field campaigns, and were found to correlate well with the maximum air temperature (MAT) measured at a nearby meteorological station. Accordingly, MAT was used as a proxy for SST on days when measurements were not available (see primary production modelling). The mean irradiance (PAR; $\mu$ mol photons $\mathrm{m}^{-2} \mathrm{~s}^{-1}$ ) was recorded at hourly intervals dur- ing 2002 and 2003 by a Licor Li-192 sensor located at the Netherlands Institute of Ecology in Yerseke, approximately $50 \mathrm{~km}$ from the field sites. Hourly PAR data was used for modelling the daily primary production of the stations throughout the period of the study.

Microphytobenthic biomass. Algal biomass was estimated from measurement of chlorophyll a (chl a). Pigments were extracted from freeze-dried contact core samples with $90 \%$ acetone. Mechanical disruption using a Bead Beater ensured an efficient release of pigment. Acetone extracts were quantified using highperformance liquid chromatography (HPLC) to give chlorophyll concentration in milligrams per square metre.

Ecosystem function: net primary production. Photosynthesis-irradiance response: Photosynthetic rates at different irradiances were measured on suspensions of microphytobenthos in filtered estuary water. The rate of photosynthesis was quantified using radiocarbon uptake (Barranguet \& Kromkamp 2000); 2 ml of optically thin microphytobenthos suspension was placed in flat-bottomed glass scintillation vials and exposed to 9 different irradiances for $30 \mathrm{~min}$. A thermostatically cooled aluminium photosynthetron was used to hold the vials in place in the light field (Lewis \& Smith 1983). The incubation temperature was set to $20^{\circ} \mathrm{C}$, and 2 replicate measurements were made on a suspension from each site. Carbon fixation rates were normalised to the algal biomass of the suspension, which was sampled in triplicate, with filters being taken before, during and after the filling of the vials. Simultaneous least-squares fitting was used to fit the cardinal parameters of the photosynthesis-irradiance curves using the target theory equation (Henley 1993). The resulting values for modelling are the light-saturated rate, $P_{\mathrm{MAX}}\left(\mathrm{mg} \mathrm{C} \mathrm{mg}^{-1} \mathrm{chl} \mathrm{a} \mathrm{h}^{-1}\right)$ and the initial slope, $\left.\alpha\left(\mathrm{mg} \mathrm{C} \mathrm{mg}^{-1} \mathrm{chl} \mathrm{a} \mathrm{h}^{-1} \text { [ } \mu \mathrm{mol} \text { photon } \mathrm{m}^{-2} \mathrm{~s}^{-1}\right]^{-1}\right)$.

Photosynthesis-temperature response: The effect of temperature on microphytobenthic photosynthesis was

Table 1. Ranges and annual means of abiotic and biotic parameters at 3 sampling sites in the Westerschelde high- (1) and mid- (2) shore stations. Standard deviations are in parentheses. Species richness and Shannon index diversity measures were calculated from species that represent a relative abundance (RA) of 1 and $5 \%$ in at least 1 sample

\begin{tabular}{|c|c|c|c|c|c|c|c|c|c|c|}
\hline & Salinity & $\begin{array}{l}\text { Water } \\
\text { content } \\
(\%)\end{array}$ & $\begin{array}{l}\text { Grain } \\
\text { size } \\
(\mu \mathrm{m})\end{array}$ & $\begin{array}{c}\text { Emersion } \\
\text { time/ light } \\
\text { hours per } 24 \mathrm{~h}\end{array}$ & $\begin{array}{c}\text { Organic } \\
\text { matter } \\
(\%)\end{array}$ & $\begin{array}{l}\text { Chloro- } \\
\text { phyll a } \\
\left(\mathrm{mg} \mathrm{m}^{-2}\right)\end{array}$ & $\begin{array}{c}\text { Net primary } \\
\text { production } \\
\left(\mathrm{mg} \mathrm{C} \mathrm{m}^{-2} \mathrm{~d}^{-1}\right)\end{array}$ & $\begin{array}{r}\text { Spec } \\
\text { inde } \\
\mathrm{RA}>1 \%\end{array}$ & $\begin{array}{l}\text { ex } \\
\text { RA > 5\% }\end{array}$ & $\begin{array}{l}\text { Shannon } \\
\text { RA > 5\% }\end{array}$ \\
\hline \multicolumn{11}{|c|}{ Appelzak } \\
\hline $\mathrm{A} 1$ & $9(5)$ & $65.7(18.1)$ & $55.8(58.7)$ & $17.8(1.5) / 14.1$ to 20.2 & $2.6(1.6)$ & 25.8 to 290.4 & -531 to 1280 & 11 to 34 & 3 to 9 & 0.14 to 1.61 \\
\hline A2 & $10.4(5)$ & $57.3(11.9)$ & $42(8.9)$ & $12.8(1.2) / 9.8$ to 14.1 & $2.3(1.2)$ & 11.6 to 292.1 & -713 to 909 & 14 to 32 & 3 to 10 & 0.26 to 1.95 \\
\hline \multicolumn{11}{|c|}{ Biezelingsche Ham } \\
\hline B1 & $21.1(4)$ & $65.4(8.6)$ & $26.2(3.6)$ & $14.2(0.6) / 13.6$ to 15.3 & $2.3(0.6)$ & 19.6 to 183.6 & -313 to 809 & 21 to 34 & 5 to 10 & 1.14 to 1.88 \\
\hline B2 & $21.3(5)$ & $52.1(7.2)$ & $45.5(16.9)$ & $11.6(0.6) / 10.9$ to 12.6 & $1.4(0.6)$ & 4 to 126.5 & -774 to 891 & 21 to 30 & 3 to 7 & 0.37 to 1.63 \\
\hline \multicolumn{11}{|c|}{ Paulina polder } \\
\hline P1 & $23.7(4)$ & $23.3(1.8)$ & $218.1(24.5)$ & $15.8(1.4) / 12.2$ to 17.6 & $0.4(0.3)$ & 18.4 to 229.2 & -2304 to $>3000$ & 20 to 28 & 2 to 8 & 0.15 to 1.50 \\
\hline P2 & $24.1(4)$ & $43.5(8.6)$ & $56.7(22.4)$ & $12.6(1.2) / 9.8$ to 13.9 & $0.8(0.5)$ & 4.7 to 163.9 & -904 to 1761 & 18 to 35 & 5 to 9 & 0.8 to 2.0 \\
\hline
\end{tabular}


not measured in this study, but has been examined in detail by Blanchard et al. $(1996,1997)$ and by Morris \& Kromkamp (2003). In these studies $\alpha$ was independent of temperature, and $P_{\mathrm{MAX}}$ had a predictable, unimodal relationship with temperature (see also similar results of Behrenfeld \& Falkowski 1997 for phytoplankton). The temperature response equations and coefficients of Blanchard et al. (1997) were used to convert $P_{\text {MAX }}$ values at $20^{\circ} \mathrm{C}$ to predicted values at the in situ SST of the site.

Respiration rate: Net primary production is the balance between gross primary carbon fixation and respiratory losses by photoautotrophs. As no data was available on the respiratory losses of microphytobenthos, it was assumed that this would vary in proportion to metabolic activity (Geider 1992). Accordingly, the respiration rate (RES) was set to a fixed value of $P_{\text {MAX }} \times$ 0.05 (Forster \& Kromkamp 2006), which should be related to the growth rate and activity of the microphytobenthic cells. Carbon losses due to exopolymer secretion and other processes such as grazing were beyond the scope of this modelling exercise.

Vertically resolved primary production model: The photosynthetic measurements described above give potential, hourly rates of carbon fixation under fixed irradiance and temperature conditions. However, natural sediments are exposed to continuously changing environmental conditions due to diurnal and bi-weekly cycles of insolation and tides (Serôdio \& Catarino 2000). Therefore, in order to predict rates of carbon fixation over a time frame appropriate for measuring changes in species composition, a modelling approach must be used (Barranguet \& Kromkamp 2000, Guarini et al. 2000). The primary production model used here featured an explicit description of irradiance conditions both at the surface and within the sediment for each of the sites.

Emersion times were calculated for each site by comparing the site elevation to measured tidal heights, which were available at 10 min time-steps from automated tidal gauges at 5 locations within the estuary (www.hmcz.nl). As tidal heights and timing of emersion periods vary along the length of the estuary, measuring gauges closest to the field sites were used. Measured water heights are preferred to predicted tidal curves because water levels in the estuary are partly dependent on wind direction. Due to the strong attenuation of irradiance by the water column of this estuary, photosynthesis was considered to be 0 during periods of immersion. Incident irradiance was calculated individually for each site, and for each hour of emersion during the period of study using the irradiance data from Yerseke.

Irradiance at the sediment surface was propagated downwards into the sediment using a sediment optical model (Forster \& Kromkamp 2004). The model assumes that irradiance is attenuated by both nonbiological material (sediment plus organic matter) and biological material (chl a). Specific attenuation coefficients of $0.011 \mathrm{~m}^{2} \mathrm{mg}^{-1}$ dry weight and $0.02 \mathrm{~m}^{2} \mathrm{mg}^{-1}$ chl a were used, respectively (Forster \& Kromkamp 2004). The distribution of chl a was defined by an exponential decrease away from the surface (Perkins et al. 2003), which is caused by the pronounced migration of cells to the surface during low-tide daytime exposures (Herlory et al. 2004). Time- and irradiancedependent differences in the shape of the chlorophyll profile, and in the surface species composition, are known to occur, but were not considered here due to the complexity of factors that can influence migration (Consalvey et al. 2004). Irradiance at depth $x\left(E_{x}\right)$ was calculated for discrete depth layers from the surface down to a depth of $2 \mathrm{~mm}$ with:

$$
E_{X, \mathrm{PAR}}=E_{(x-z, \mathrm{PAR})} \times \mathrm{e}^{-k_{d(\text { sum })} \times z}
$$

where $k_{d \text { (sum) }}$ is the sum of attenuation due to biological and non-biological material and $z$ is the depth interval $(10 \mu \mathrm{m})$.

From the irradiance and biomass at each depth, net hourly rates of photosynthesis at each depth were calculated according to:

$$
P_{z}=\left[P_{\max } \times\left(1-\mathrm{e}^{-\alpha \cdot E_{(z, \mathrm{PAR})} / P_{\max }}\right)-\mathrm{RES}\right] \times \operatorname{chl} a
$$

Net photosynthetic rates were integrated over the upper $1 \mathrm{~mm}$ of the sediment in order to give the areal hourly primary production in milligrams carbon per square metre. Integration over a $24 \mathrm{~h}$ period was then performed in order to calculate the daily net primary production for each site $\left(P_{\mathrm{n} i} \mathrm{mg} \mathrm{C} \mathrm{m} \mathrm{C}^{-1}\right)$, which is our desired measure of ecosystem function (Costanza et al. 1993, Herman et al. 1999). Note that negative net production estimates can arise when respiratory losses during periods of low irradiance and darkness outweigh carbon gains due to photosynthesis. The mean daily $P_{\mathrm{n}}$ for a period of $5 \mathrm{~d}$ before the collection of microphytobenthic samples was used for comparison with biodiversity data. This period was chosen to reflect the time required for species shifts to occur in relatively slowly growing microphytobenthic biofilms.

Microphytobenthos counts and biodiversity. Microscopic observations of live samples and HPLC analysis of accessory pigments indicated that diatoms were the dominant algal group at all sites. In order to visualise the ultrastructural features of the siliceous cell wall for identification and counting purposes, samples were oxidised with a 1:1 mixture of hydrogen peroxide (30\%) and acetic acid (100\%) and rinsed several times with distilled water. Oxidised materials were then mounted in Naphrax. Identifications and relative cell counts were made using a Leitz Diaplan microscope equipped with 
Differential Interference Contrast. Identifications were based on Sabbe (1997). Per sample, ca. 300 diatom valves were counted (min. 277, max. 336), and relative abundances calculated. Microscopic analyses of live and fixed materials allowed assignment of all taxa to the following 4 functional categories on the basis of their predominant growth form: (1) epipsammic (attached to or closely associated with individual sand grains); (2) epipelic (free-living); (3) tychoplankton (diatoms which are frequently encountered both in the water column and sediments [Vos \& de Wolf 1993], and which may have an amphibious life style) and (4) true plankton.

Biodiversity measures used were species richness (total number of species: SR) and the Shannon index ( $H^{\prime}$, Magurran 1988), which was calculated using the program Primer 5 for Windows (Version 5.2.2). Biodiversity calculations were based on the abundance data of benthic diatoms and epipelic species, which reach a relative abundance of 1 and $5 \%$ in at least 1 sample, respectively.

\section{RESULTS}

Diverse sets of environmental parameters were encountered at the 6 stations in the course of the study. Lowest salinity values were recorded at Stns A1 and A2, with intermediate values at B1 and B2 and highest values at P1 and P2 (Table 1). Sediment composition ranged from muddy sand with a high water and organic matter content at Stns A1, A2, B1 and B2 to fine sand at Stn P1 (Table 1). The microalgal pigment concentrations were significantly different according to collection dates (ANOVA, df = 7, F = 4.67, p < 0.0001), but not for the site or station. Multiple comparison indicated that the chl a was lower in February $\left(23 \mathrm{mg} \mathrm{m}^{-2}\right.$ ) and September $\left(29 \mathrm{mg} \mathrm{m}^{-2}\right)$ compared to March $\left(97 \mathrm{mg} \mathrm{m}^{-2}\right)$, April (171 $\mathrm{mg} \mathrm{m}^{-2}$ ) and May 2003 (112 $\mathrm{mg} \mathrm{m}^{-2}$ ). The highest microalgal biomass was recorded at Stns A1 and A2. At these 2 sites there was a clearly defined spring bloom beginning in March and ending in May, with low biomass throughout the summer and winter. In contrast, a broader peak in biomass values was found at Stn P1 from April to September. The lowest biomass was found at B2, which had the lowest elevation and thus received the least amount of light.

In total 158 diatom taxa were identified in the samples collected between May
2002 and September 2003. The proportions of the different diatom functional groups varied according to collection site. The least abundant group was composed of the epipsammic diatoms. Their contribution for all stations was particularly low, $<6 \%$, except for Stn P1, where this group represented on average $54 \%$. The abundance of planktonic diatoms was also low, between 1 and $17 \%$. The tychoplanktonic diatoms showed a very large range of abundance from $4 \%$ (P1) to $39 \%$ (P2). The contribution of epipelic diatoms was consistently highest at Site A, with a mean annual value of $57 \%$ at A1 and $53 \%$ at A2 and mean abundances of between 30 and $35 \%$ for Sites B and P. The diatoms in this functional group were particularly well represented in March and May for all stations; 17 species of epipelic diatoms were identified as the numerically dominant taxa in the estuary (Fig. 2), composed mainly of species from the group of Navicula. This species complex represented between 87 and $99 \%$ of the epipelic diatoms. Site A showed a different epipelic species composition compared to B and $\mathrm{P}$ (Fig. 2). N. flanatica was the dominant species at A1 and $\mathrm{A} 2$, whereas $N$. gregaria was dominant in $\mathrm{P} 1$ and $N$. arenaria var. rostellata at P2. Stns B1 and B2 did not show any dominant species. Other species such as $N$. phyllepta and $N$. perminuta were present at all stations, but with lower abundance. Except for P1 and P2 (sandy versus muddy station), species composition did not differ between the upper and mid-shore elevations within the intertidal transects (Fig. 2). Within any sample, the num-

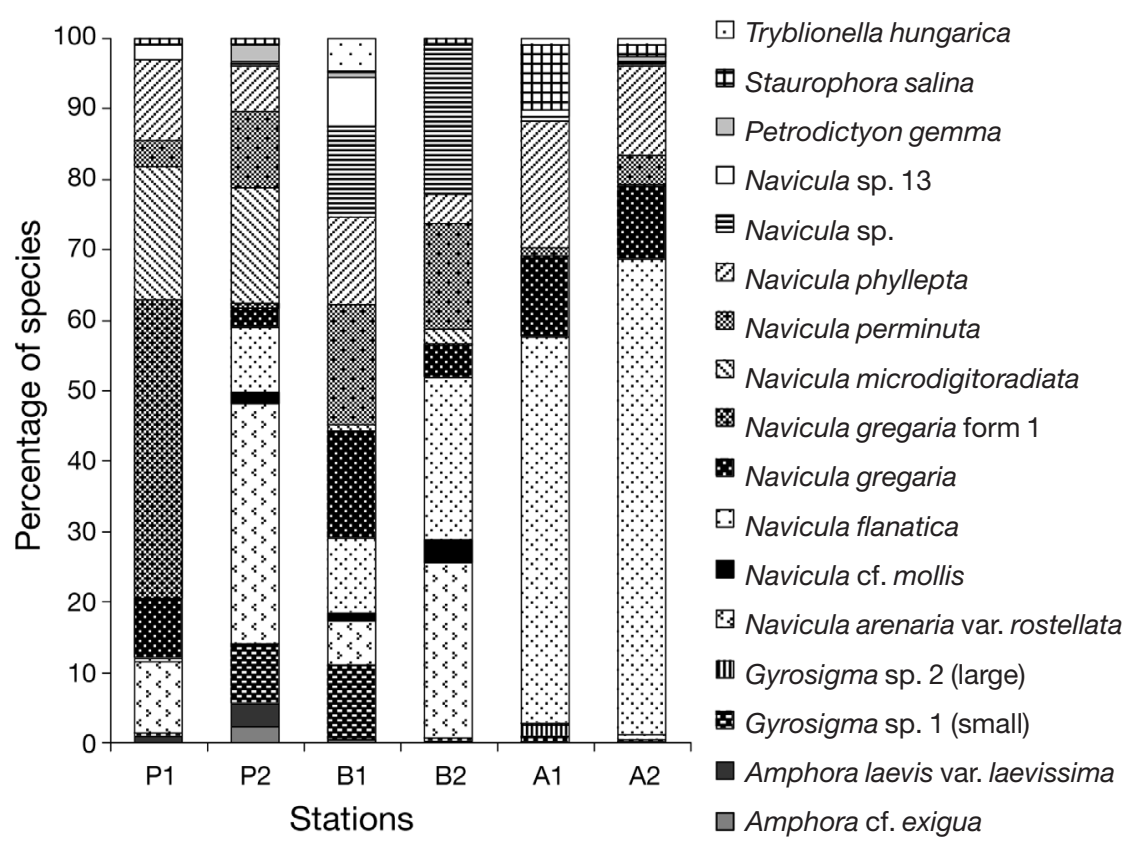

Fig. 2. Species distributions of epipelic diatoms encountered at the 6 collection sites. Relative abundance of species was calculated from 8 field campaigns between May 2002 and September 2003. P: Paulina polder; B: Biezelingsche Ham; A: Appelzak; 1: upper shore; 2 : mid shore 
ber of dominant epipelic diatoms (e.g. relative abundance $>5 \%$ ) was always $>2$, but $<10$ (Table 1 ). The contribution of the functional groups varied according to the chl a concentration of the biofilm, with a significant shift $\left(\mathrm{R}^{2}=0.56, \mathrm{p}<0.001, \mathrm{n}=48\right)$ towards a dominance of epipelic species as biomass increased (Fig. 3).

The relationship between microalgal biomass and biodiversity (species richness) differed depending on whether total diatom species or only epipelic diatom species were considered. The total number of diatom species from all groups showed a weak but significant negative relationship with increasing biomass $\left(R^{2}=\right.$ $0.28, \mathrm{p}<0.001, \mathrm{n}=48$ ), whereas the most important functional group, epipelic diatoms, did not show any significant relationship ( $\mathrm{p}=0.38$, Fig. 4 ). The same trends were also found when the Shannon index was used as the diversity measure.

Due to a low variability in the photosynthetic parameters $P_{\mathrm{MAX}}$ and $\alpha$, areal net primary production was determined primarily by a combination of the amount of photosynthetically active biomass, length of photoperiod, the incident irradiance during emersion and the SST. Thus, predicted daily $P_{\mathrm{n}}$ was lowest (negative: $-304 \mathrm{mg} \mathrm{C} \mathrm{m}^{-2} \mathrm{~d}^{-1}$ ) at Stn A1 in March 2003 during a period of cloudy weather when respiratory losses were in excess of photosynthetic gains. The highest estimated $P_{\mathrm{n}}$ value was recorded at P1 in May 2002 (3635

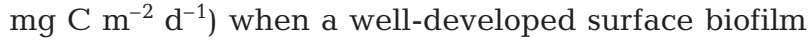
was exposed to several days of high irradiance and favourable temperatures. As carbon fixation rates in the model were not constrained by the availability of dissolved inorganic carbon (DIC) in the sediment porewater, it is highly likely that the model overestimated net daily production at P1 in May 2002. DIC limitation is known to be important in dense microphytobenthic communities (Admiraal 1984). Modelled $P_{\mathrm{n}}$ for Sites A, B and P showed sitespecific relationships with biodiversity, but the strength of effect was dependent upon the choice of index (Fig. 5a,b). Regardless of the indices, Site A showed a significant, positive relationship $\left(\mathrm{R}^{2}=0.5, \mathrm{p}<0.01, \mathrm{n}=13\right)$ between $P_{\mathrm{n}}$ and species richness or Shannon index. However, the net primary production decreased when the number of species was $>8$ (Fig. 5a) or when the Shannon index was superior to 1.6 (Fig. 5b). Site B also showed a significant positive relationship between $P_{\mathrm{n}}$ and Shannon index $\left(\mathrm{R}^{2}=0.3, \mathrm{p}<0.01, \mathrm{n}=13\right)$, but not with the species richness. The speciesrichness data from Site P followed for both indices a unimodal distribution, showing that the highest net primary production occurred for an intermediate species richness of 5 and Shannon index of 1.2 (Fig. 5a,b).

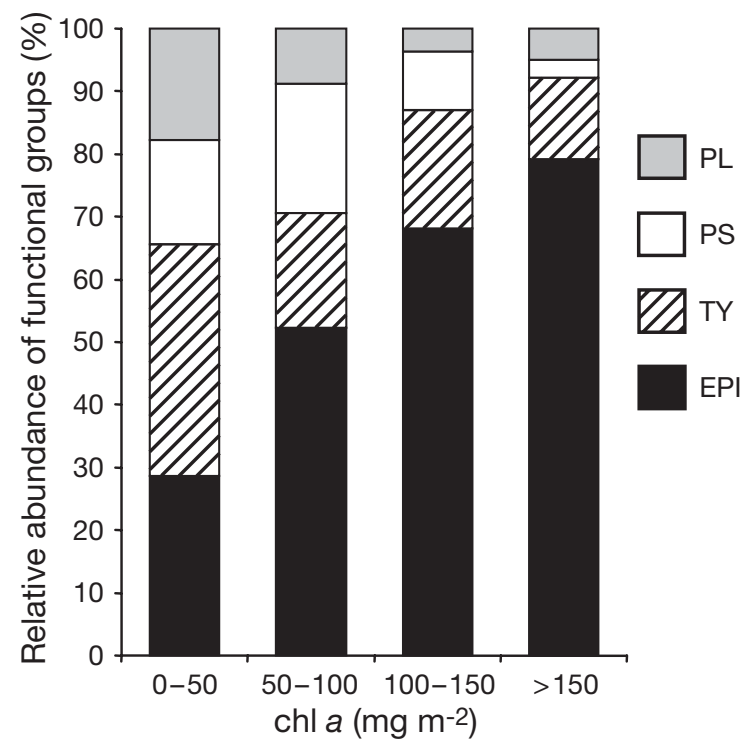

Fig. 3. Relative abundance of functional groups (PL: planktonic; PS: episammic; TY: tychoplanktonic; EPI: epipelic) of diatoms recorded in sediment samples between May 2002 and September 2003. The dataset was subdivided according to the chlorophyll a ( $\mathrm{chl} \mathrm{a}$ ) concentration $\left(\mathrm{mg} \mathrm{m}^{-2}\right)$ at the collection sites

\section{DISCUSSION}

The importance of biodiversity from an anthropocentric viewpoint is to maintain the useful characteristics of an ecosystem, which are the patterns and the rates of biochemical process, in the face of changes in the external environment. The theoretical foundations, as well as the experimental approach required to understand marine biodiversity and ecosystem function, are

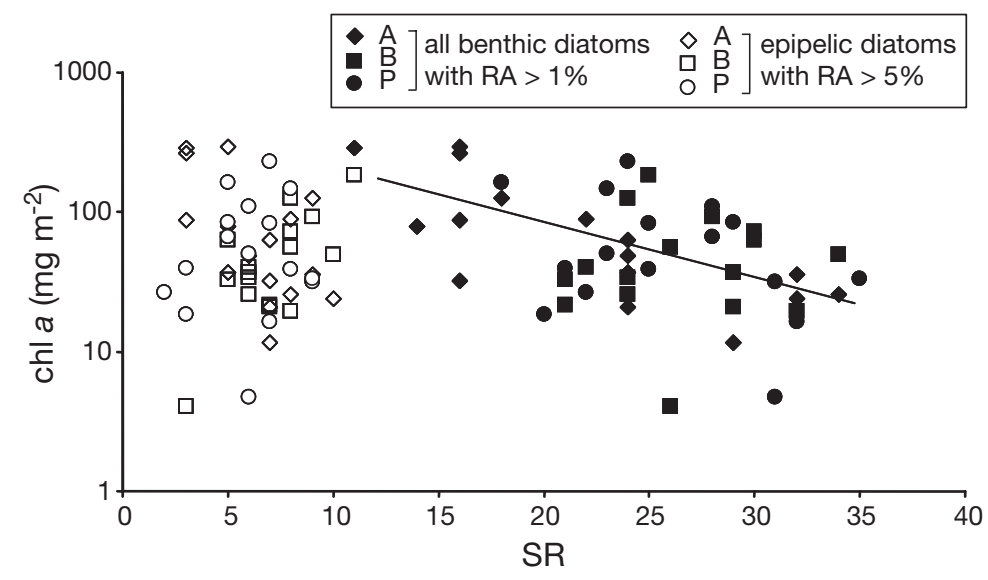

Fig. 4. Biomass ( $\mathrm{chl} \mathrm{a}$ in $\mathrm{mg} \mathrm{m}^{-2}$ ) as a function of species richness (SR) for all benthic diatoms with a relative abundance (RA) $>1 \%$ (filled symbols) and epipelic diatoms with RA > 5\% (open symbols) in at least 1 sample at Appelzak (A: $\diamond)$, Biezelingsche Ham (B: $\square$ ) or Paulina polder (P: O). Linear regression: $\mathrm{R}^{2}=0.28, \mathrm{p}<0.001, \mathrm{n}=48$ for benthic diatoms with RA $>1 \%$ 

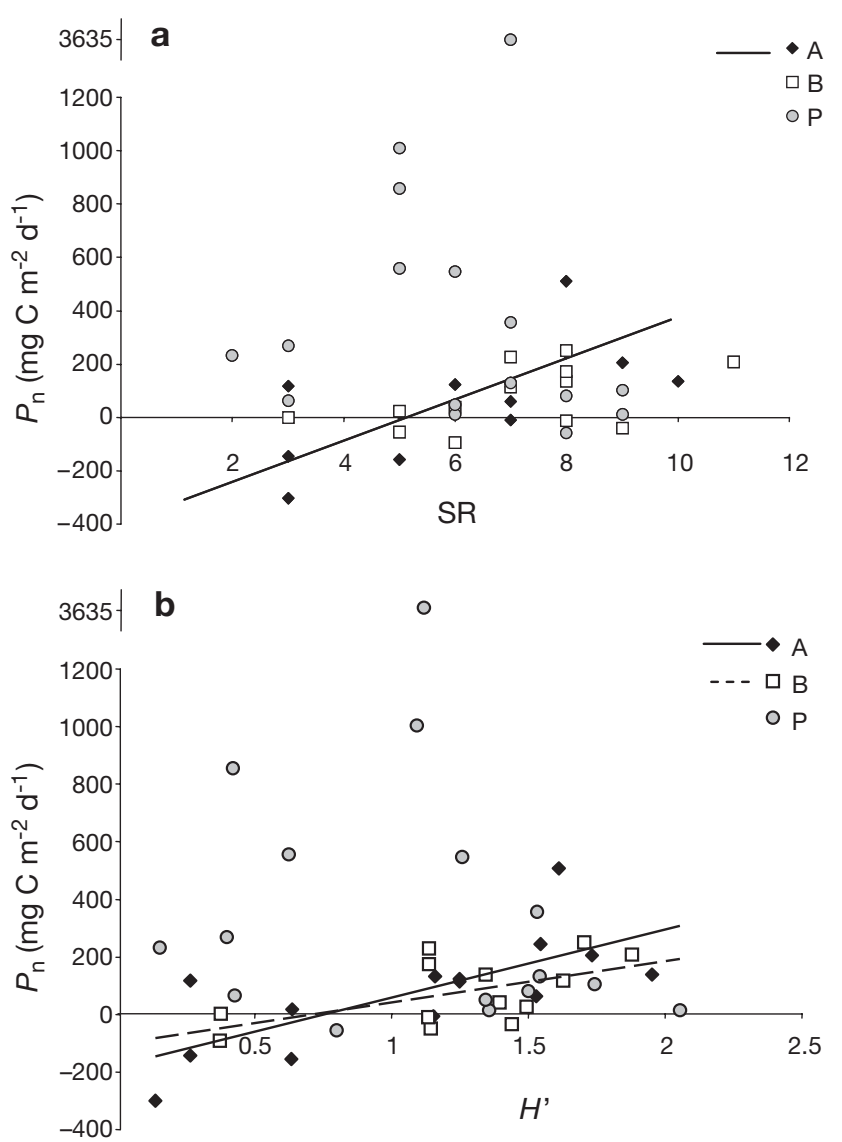

Fig. 5. Net primary production $\left(P_{\mathrm{n}}: \mathrm{mg} \mathrm{C} \mathrm{m}^{-2} \mathrm{~d}^{-1}\right)$ as a function of diversity indices: (a) species richness (SR) and (b) Shannon index $\left(H^{\prime}\right)$, for Appelzak (A: $\bullet$ ), Biezelingsche Ham (B: $\square$ ) and Paulina polder ( $\mathrm{P}: \mathrm{O})$. Linear regression: Panels a \& $\mathrm{b}: \mathrm{R}^{2}=0.5$, $\mathrm{p}<0.01, \mathrm{n}=13$ for Appelzak; Panel b: $\mathrm{R}^{2}=0.3, \mathrm{p}<0.01, \mathrm{n}=13$ for Biezelingsche Ham

very poorly developed compared to terrestrial ecology, and it remains to be seen whether terrestrial and marine systems are similar enough to allow theory from one domain to be used for the other (Covich et al. 2004). For example, marine systems are characterised by low population densities of small autotrophic primary producers being responsible for a disproportionately large amount of organic matter production (Heip et al. 2003). Thus, the standing stock of autotrophs may not be synonymous with primary production, as has been assumed in many terrestrial diversity-function experiments (Hector et al. 1999), but also in studies on marine phytoplankton (Irigoien et al. 2004). The expression of biodiversity also differs between studies. This can be the number of species as well as different indices (Gray 2000). In addition to these differences in processes and index definition, there are also different spatial scales and trophic levels to consider. Thus, comparison of diversity-function relationships between different studies is difficult. In this study, 2 measures of ecosystem function were chosen: (1) chl $a$ to represent the biomass of microalgal primary producers, which is an important food source for benthic invertebrates, and (2) the net primary production of the microalgae, which is closely related to growth rate and the resilience of the surface biofilm to losses. We expressed the level of biodiversity and its heterogeneity by species richness and the Shannon index.

Estuarine benthic diatom assemblages are species rich, with patterns of distribution and relative abundance of different species that vary consistently over seasonal and spatial scales (Admiraal 1984). Although careful autoecological work has revealed the preferences of different species for particular niches (Underwood \& Provot 2000), there is no consensus as to the main factors that determine community composition at the estuary scale. Some studies have highlighted the importance of sediment composition (e.g. Paterson \& Hagerthy 2001), in others, sediment ammonium concentration appeared to be an important factor influencing the distribution of benthic diatom species in salt marshes (Sullivan 1999) and mudflats (Peletier 1996, Underwood et al. 1998). In the Westerschelde there are consistent differences in species composition along the gradients of sediment composition and salinity (Sabbe \& Vyverman 1991) in terms of relative abundance (see also Fig. 2), but most species can be described as euryhaline, particularly in the Navicula group.

In spite of the variations in salinity and tidal height, which one would expect to negatively affect the number of species, the Westerschelde estuary presents a high number of diatom taxa compared to other mudflat ecosystems (e.g. Ribeiro et al. 2003 for the Tagus estuary; Thornton et al. 2002 for the Colne estuary). However, only a limited number of species had a high enough relative abundance to be classed as important in ecosystem function. Seventeen of these were epipelic, and the majority belonged to the genus Navicula, which are also key players in other tidal estuaries (Admiraal \& Peletier 1980, Colijn \& Dijkema 1981, Oppenheim 1991).

Species richness relative to total microphytobenthic diatoms showed a significant inverse relationship with biomass. This relationship was not significant when only epipelic species were considered. However, as in the study by Colijn \& Dijkema (1981), we found that sites with high biomasses showed dominance by a single species, or a low number of species (Fig. 4). Notably, the shape of the biomass-diversity curve for microphytobenthos differs from that for phytoplankton, for which both low and high biomass events are associated with low taxonomic diversity (Irigoien et al. 2004). As in phytoplankton, biodiversity was also suppressed at high cell densities occurring during the bloom periods of microphytobenthos, possibly due to 
competitive interactions for limiting resources. However, in the microphytobenthic community of the Westerschelde, low biomasses were generally associated with high rather than low diversity. In winter and early spring, when conditions were unfavourable for growth and chlorophyll concentrations were low, a diverse mix of species appeared to be present. These cells probably form the seed population for rapid biofilm development in spring. It is likely that there are strong founder effects in intertidal sediments, as in certain other aquatic ecosystems (De Meester et al. 2002). A fixed set of more competitive species, particular to each site, then monopolised the space in the upper sediment throughout the period of favourable growth. Epipelic species were dominant during this phase, but monospecific biofilms were not recorded. Rather, dominance was shared by a small number of species (typically 2 to 10), suggesting that there may be niche differentiation within the upper millimetres of the sediment photic zone. Species-specific differences in the depth or timing of migratory movements between the nutrient-rich aphotic zone and the nutrient-poor photic zone could be one mechanism of niche separation (Saburova \& Polikarpov 2003). The low number of dominant species and the regular appearance of the same set of species at particular sites suggest that this phase of the microphytobenthic system may be resistant to invasion by non-native species. Later in the year, low levels of chlorophyll were recorded at the low- and mid-salinity sites. This was probably driven by grazing and not by lack of nutrients, as porewater and estuarine water nutrients were at all times in excess of growth requirements. A high rate of grazing may promote diversity (and boost production, see below) by selective removal of the larger epipelic species (Hagerthey et al. 2002). In epilithic communities the effect of grazing on algal diversity was dependent upon the level of nutrient enrichment (Worm et al. 2002). A caveat must be added to this analysis: the dataset was obtained from field observations, in which neither biodiversity nor ecosystem function were manipulated experimentally. The biodiversity-function relationships that were apparent could also be a result of independent responses of each variable to changes in other parameters. So-called 'hidden' treatments in biodiversity-function experiments have been of major concern to terrestrial ecologists (Huston 1997).

In the marine environment, studies on the relationship between diversity and functioning are still rare, and the most common index of ecosystem function has been the rate and direction of inorganic nutrient flow between benthic and pelagic compartments (Emmerson et al. 2001, Covich et al. 2004). Primary production in phytoplankton from different sites generally showed a positive relationship with increasing species richness (Vadrucci et al. 2003). Although there have been many studies of benthic primary production (see Underwood \& Kromkamp 1999), none have directly linked production rates to species composition. Since the base of the trophic web in marine systems is dominated by singlecelled algae, with a high (and variable) ratio of production to biomass, it is inappropriate to use microalgal standing stock as an index of primary production (see discussion in Emmerson \& Huxham 2003). Indeed, no correlation was observed in the dataset described here between microphytobenthic biomass and estimated $P_{\mathrm{n}}$. The approach used here is therefore to model net production from a combination of photosynthetic measurements, algal abundance, sediment optical conditions and abiotic factors. Although our model was not detailed enough to account for within-day changes in species composition at the sediment surface, the performance of the model was tested in a laboratory mesocosm experiment in which the growth of a mixedspecies microphytobenthic biofilm was followed in detail for $2 \mathrm{wk}$. In that experiment, calculated values of $P_{\mathrm{n}}$ closely followed changes in carbon biomass as a biofilm developed (Morris 2005). The direct approach to the measurement of primary production, based on intensive, repeated sampling of cell number, carbon, or chlorophyll over relevant periods (e.g. spring-neap tidal cycle, Herlory et al. 2004) could be preferable to the modelling approach used here, especially in situations where losses due to grazing and resuspension are low, but for logistical reasons could not be performed with the multiple sites and seasons of this study.

The present study only involves 1 trophic level and takes into account the function of species in 1 taxonomic group: the epipelic diatoms. A linear relationship between chlorophyll concentration and the abundance of epipelic cells was found, thus confirming that the epipelon was the dominant functional component of biofilms in the Westerschelde, as in other estuaries (MacIntyre et al. 1996, Underwood \& Kromkamp 1999). In addition, epipelic cells migrate up to the sediment surface during daytime tidal emersion (Serôdio 2003). Thus, this group dominated not only the bulk chlorophyll, but also formed a large part of the photosynthetically active biomass, that is, the cells which are optimally positioned to intercept light. The relationship between species diversity (either richness or $H^{\prime}$ ) and $P_{\mathrm{n}}$ differed widely between sites within the estuary. The results should be interpreted with caution, as biodiversity was not deliberately manipulated as an independent variable in this study. The low- and midsalinity sites (A \& B) both showed significantly increasing rates of net production as biodiversity increased. Sampling events during periods of low or negative net production (mainly driven by low irradi- 
ance) were associated with low species richness and Shannon indices, which can be interpreted in 2 ways (Gessner et al. 2004). Either some species were sensitive to this form of environmental stress, which caused a decrease in biodiversity, or the low number of species was responsible for decreased rates of production. The latter scenario is perhaps less likely as biomassnormalised maximum rates of photosynthesis were relatively constant throughout the study. Site P at the seaward end of the estuary also showed low $P_{\mathrm{n}}$ at the lowest levels of diversity, but showed much higher rates of production at intermediate levels of diversity. All 3 sites showed similar $P_{\mathrm{n}}$ at the highest levels of diversity, e.g. species richness $>10$ and Shannon $H^{\prime}>$ 1.8. The dissimilarity in the response of microphytobenthos at Site P can be explained by the later appearance and slower decline of the spring biomass maximum at this site, possibly due to lower rates of grazing. Diatom biofilms persisted into late spring or summer at the high-shore site, and therefore encountered improved conditions of light and temperature for photosynthesis. Interestingly, these more favourable environmental circumstances did not feed back at the community level to an increased level of biodiversity. This may be related to the fact that many species may not be able to withstand drying out of the sediments during the warmer months of the year. Alternatively, the different diversity-production relationships may be related to the fact that epipsammic diatoms, which were not taken into account in our analyses, may have significantly contributed to production at the more sandy station (P1).

\section{CONCLUSIONS}

Studies of the biodiversity-function relationship began in terrestrial ecology, and the main question for the marine ecologist is: Can we use the same hypotheses and the same tools in the marine environment? According to Emmerson \& Huxham (2003) there are considerable advantages of using biomass as a measure of functioning in terrestrial ecology. However, in the marine coastal environment, changes in standing stock may be impossible to determine for each species, due to the open nature of the ecosystem. Moreover, the biomass represents the standing stock of organic matter, but may not reflect ecosystem metabolism if turnover rates are high. The results confirmed that biomass and primary production were not interchangeable, as they did not show the same relationship with diversity.

Site-specific differences were also found, especially in the relationships of $P_{\mathrm{n}}$ and biodiversity. Two sites showed that the enrichment of a key benthic functional group was related to enhanced production, but at the third site an intermediate level of richness corresponded to the highest level of production. The causes of this variability in the relationship are multiple. The scale of the study seems to be one of the factors (Chase \& Leibold 2002), due to variability in abiotic parameters along the estuary, such as salinity, sedimentation dynamics and nutrient supply. All these parameters drive the composition of the diatom community, as well as that of associated bacterial communities and consumers. Thus, the developmental history of the biofilm will influence the observed rates of ecosystem processes (Fukami \& Morin 2003). Experimental manipulations of diatom species richness under conditions in which abiotic parameters can be controlled, such as in climate-controlled tidal mesocosms, may give more direct insights into the functional consequences of biodiversity change. Finally, in order to have a better picture of the diversity-processes relationship in intertidal sediments, future studies should also take multiple trophic levels into account by manipulating consumer abundance.

Acknowledgements. This study was financed by EU Program Number EVK3-CT-2001-00052 'A system of hierarchical monitoring methods for assessing changes in the biological and physical state of intertidal areas' and the Dutch-Flemish Cooperation Program for Marine Research (VLaNeZo) Project Number 832.11.003;13 and BOF-GOA Project 01G00705 (Ghent University, Belgium). Renaat Dasseville and Jan Peene gave expert assistance during field sampling and production measurements. This is NIOO-KNAW Publication Number 3682.

\section{LITERATURE CITED}

Admiraal W (1984) The ecology of estuarine sediment-inhabiting diatoms. Prog Phycol Res 3:271-318

Admiraal W, Peletier HDSB (1980) Distribution of diatom species on an estuarine mud flat and experimental analysis of the selective effect of stress. J Exp Mar Biol Ecol 46: $157-175$

Barranguet C, Kromkamp J (2000) Estimating primary production rates from photosynthetic electron transport in estuarine microphytobenthos. Mar Ecol Prog Ser 204: $39-52$

Behrenfeld MJ, Falkowski PG (1997) Photosynthetic rates derived from satellite-based chlorophyll concentration. Limnol Oceanogr 42:1-20

Blanchard GF, Guarini JM, Richard P, Gros P, Mornet F (1996) Quantifying the short-term temperature effect on lightsaturated photosynthesis of intertidal microphytobenthos. Mar Ecol Prog Ser 134:309-313

Blanchard GF, Guarini JM, Gros P, Richard P (1997) Seasonal effect on the relationship between the photosynthetic capacity of intertidal microphytobenthos and temperature. J Phycol 33:723-728

Cahoon LB (1999) The role of benthic microalgae in neritic ecosystems. Oceanogr Mar Biol Annu Rev 37:47-86

Chase JM, Leibold MA (2002) Spatial scale dictates the productivity-biodiversity relationship. Nature 416:427-429 
Colijn F, Dijkema KS (1981) Species composition of benthic diatoms and distribution of chlorophyll $a$ on an intertidal flat in the Dutch Wadden Sea. Mar Ecol Prog Ser 4:9-21

Consalvey M, Paterson DM, Underwood GJC (2004) The ups and downs of life in a benthic biofilm: migration of benthic diatoms. Diatom Res 19:181-202

Costanza R, Kemp WM, Boynton WR (1993) Predictability, scale, and biodiversity in coastal and estuarine ecosystems-implications for management. Ambio 22:88-96

Covich AP, Austen MC, Barlocher F, Chauvet E and 8 others (2004) The role of biodiversity in the functioning of freshwater and marine benthic ecosystems. BioScience 54: 767-775

Defew EC, Paterson DM, Hagerthey SE (2002) The use of natural microphytobenthic assemblages as laboratory model systems. Mar Ecol Prog Ser 237:15-25

De Meester L, Gomez A, Okamura B, Schwenk K (2002) The monopolization hypothesis and the dispersal-gene flow paradox in aquatic organisms. Acta Oecol Int J Ecol 23: 121-135

Dunstan GA, Volkman JK, Barrett SM, Leroi JM, Jeffrey SW (1994) Essential polyunsaturated fatty-acids from 14 species of diatom (Bacillariophyceae). Phytochemistry 35:155-161

Emmerson MC, Huxham M (2003) How can marine ecology contribute to the biodiversity-ecosystem functioning debate? In: Loreau M, Naeem S, Inchausti P (eds) Biodiversity and ecosystem functioning, synthesis and perspectives. Oxford University Press, Oxford, p 139-146

Emmerson MC, Solan M, Emes C, Paterson DM, Raffaelli D (2001) Consistent patterns and the idiosyncratic effects of biodiversity in marine ecosystems. Nature 411:73-77

Ford RB, Honeywill C (2002) Grazing on intertidal microphytobenthos by macrofauna: is pheophorbide a a useful marker? Mar Ecol Prog Ser 229:33-42

Forster RM, Kromkamp JC (2004) Modelling the effects of chlorophyll fluorescence from subsurface layers on photosynthetic efficiency measurements in microphytobenthic algae. Mar Ecol Prog Ser 284:9-22

Forster RM, Kromkamp JC (2006) Estimating benthic primary production: scaling up from point measurements to the whole estuary. In: Kromkamp JC, de Brouwer JFC, Blanchard GF, Forster RM, Creach V (eds) Functioning of microphytobenthos in estuaries. KNAW, Amsterdam

Fukami T, Morin PJ (2003) Productivity-biodiversity relationships depend on the history of community assembly. Nature 424:423-426

Gattuso JP, Frankignoulle M, Wollast R (1998) Carbon and carbonate metabolism in coastal aquatic ecosystems. Annu Rev Ecol Syst 29:405-434

Gazeau F, Smith SV, Gentili B, Frankignoulle M, Gattuso JP (2004) The European coastal zone: characterization and first assessment of ecosystem metabolism. Estuar Coast Shelf Sci 60:673-694

Geider RJ (1992) Respiration: taxation without representation. In: Falkowski PG, Woodhead AD (eds) Primary productivity and biogeochemical cycles in the sea. Plenum, New York

Gessner MO, Inchausti P, Persson L, Raffaelli DG, Giller PS (2004) Biodiversity effects on ecosystem functioning: insights from aquatic systems. Oikos 104:419-422

Gray JS (2000) The measurement of marine species diversity, with an application to the benthic fauna of the Norwegian continental shelf. J Exp Mar Biol Ecol 250:23-49

Guarini JM, Blanchard GF, Gros P, Gouleau D, Bacher C (2000) Dynamic model of the short-term variability of microphytobenthic biomass on temperate intertidal mudflats. Mar Ecol Prog Ser 195:291-303
Hagerthey SE, Defew EC, Paterson DM (2002) Influence of Corophium volutator and Hydrobia ulvae on intertidal benthic diatom assemblages under different nutrient and temperature regimes. Mar Ecol Prog Ser 245:47-59

Hector A, Schmid B, Beierkuhnlein C, Caldeira MC and 30 others (1999) Plant diversity and productivity experiments in European grasslands. Science 286:1123-1127

Heip CHR, Goosen NK, Herman PMJ, Kromkamp J, Middelburg JJ, Soetaert K (1995) Production and consumption of biological particles in temperate tidal estuaries. Oceanogr Mar Biol Annu Rev 33:1-149

Heip C, Brandt A, Gattuso JP, Anita A and 12 others (2003) Ecosystem functioning and biodiversity. In: Wefer $G$, Lamy F, Mantoura F (eds) Marine science frontiers for Europe. Springer-Verlag, Berlin

Henley WJ (1993) Measurement and interpretation of photosynthetic light-response curves in algae in the context of photoinhibition and diel changes. J Phycol 29:729-739

Herlory O, Guarini JM, Richard P, Blanchard GF (2004) Microstructure of microphytobenthic biofilm and its spatio-temporal dynamics in an intertidal mudflat (Aiguillon Bay, France). Mar Ecol Prog Ser 282:33-44

Herman PMJ, Middelburg JJ, Van de Koppel J, Heip CHR (1999) Ecology of estuarine macrobenthos. Adv Ecol Res 29:195-240

Huston MA (1997) Hidden treatments in ecological experiments: re-evaluating the ecosystem function of biodiversity. Oecologia 110:449-460

Irigoien X, Huisman J, Harris RP (2004) Global biodiversity patterns of marine phytoplankton and zooplankton. Nature 429:863-867

Lewis MR, Smith JC (1983) A small volume, short-incubationtime method for measurement of photosynthesis as a function of incident irradiance. Mar Ecol Prog Ser 13:99-102

Loreau M (2000) Biodiversity and ecosystem functioning: recent theoretical advances. Oikos 91:3-17

MacIntyre HL, Geider RJ, Miller DC (1996) Microphytobenthos-the ecological role of the secret garden of unvegetated, shallow-water marine habitats. 1. Distribution, abundance and primary production. Estuaries 19:186-201

Magurran AE (1988) Ecological diversity and its measurement. Princeton University Press, Princeton

Middelburg JJ, Duarte CM, Gattuso JP (2005) Respiration in coastal benthic communities. In: del Giorgio PA, Williams $\mathrm{P}$ (eds) Respiration in aquatic systems. University of Wales, Bangor

Morris EP (2005) Quantifying primary production of microphytobenthos: application of optical methods. $\mathrm{PhD}$ thesis, University of Groningen, Groningen

Morris EP, Kromkamp JC (2003) Influence of temperature on the relationship between oxygen and fluorescence-based estimates of photosynthetic parameters in a marine benthic diatom (Cylindrotheca closterium). Eur J Phycol 38: $133-142$

Oppenheim DR (1991) Seasonal changes in epipelagic diatoms along an intertidal shore, Berrow Flats, Somerset. J Mar Biol Assoc UK 71:579-596

Paterson DM, Hagerthey SE (2001) Microphytobenthos in contrasting coastal ecosystems: biology and dynamics. In: Reise K (ed) Ecological studies, Vol 151. Ecological comparisons of sedimentary shores. Springer-Verlag, Berlin, p 105-125

Peletier H (1996) Long-term changes in intertidal estuarine diatom assemblages related to reduced input of organic waste. Mar Ecol Prog Ser 137:265-271

Perkins RG, Honeywill C, Consalvey M, Austin HA, Tolhurst TJ, Paterson DM (2003) Changes in microphytobenthic 
chlorophyll $a$ and EPS resulting from sediment compaction due to de-watering: opposing patterns in concentration and content. Cont Shelf Res 23:575-586

Ribeiro L, Brotas V, Mascarell G, Coute A (2003) Taxonomic survey of the microphytobenthic communities of two Tagus estuary mudflats. Acta Oecol Int $\mathrm{J}$ Ecol 24: $117-123$

Sabbe K (1997) Systematics and ecology of intertidal benthic diatoms of the Westerschelde estuary (The Netherlands). Thesis, University of Ghent, Ghent

Sabbe K, Vyverman W (1991) Distribution of benthic diatom assemblages in the Westerschelde (Zeeland, The Netherlands). Belg J Bot 124:91-101

Saburova MA, Polikarpov IG (2003) Diatom activity within soft sediments: behavioural and physiological processes. Mar Ecol Prog Ser 251:115-126

Serôdio J (2003) A chlorophyll fluorescence index to estimate short-term rates of photosynthesis by intertidal microphytobenthos. J Phycol 39:33-46

Serôdio J, Catarino F (2000) Modelling the primary productivity of intertidal microphytobenthos: time scales of variability and effects of migratory rhythms. Mar Ecol Prog Ser 192:13-30

Sullivan MJ (1999) Applied diatom studies in estuarine and shallow coastal environments. In: Stoermer EF, Smol JP (eds) The diatoms: applications for the environmental and earth sciences. Cambridge University Press, Cambridge, p 334-351

Sundbäck K, Miles A, Goransson E (2000) Nitrogen fluxes, denitrification and the role of microphytobenthos in microtidal shallow-water sediments: an annual study. Mar Ecol Prog Ser 200:59-76

Thornton DCO, Dong LF, Underwood GJC, Nedwell DB (2002) Factors affecting microphytobenthic biomass, species composition and production in the Colne estuary (UK). Aquat Microb Ecol 27:285-300

Editorial responsibility: Martin Solan (Guest Editor), Newburgh, UK
Tolhurst TJ, Jesus B, Brotas V, Paterson DM (2003) Diatom migration and sediment armouring - an example from the Tagus estuary, Portugal. Hydrobiologia 503:183-193

Underwood GJC, Kromkamp J (1999) Primary production by phytoplankton and microphytobenthos in estuaries. Adv Ecol Res 29:93-153

Underwood GJC, Provot L (2000) Determining the environmental preferences of four estuarine epipelic diatom taxa: growth across a range of salinity, nitrate and ammonium conditions. Eur J Phycol 35:173-182

Underwood GJC, Phillips J, Saunders K (1998) Distribution of estuarine benthic diatom species along salinity and nutrient gradients. Eur J Phycol 33:173-183

Vadrucci MR, Vignes F, Fiocca A, Basset A, Santarpia I, Carrada GC, Cabrini M, Umani SF (2003) Space-time patterns of co-variation of biodiversity and primary production in phytoplankton guilds of coastal marine environments. Aquat Conserv 13:489-506

Vos PC, de Wolf H (1993) Diatoms as a tool for reconstructing sedimentary environments in coastal wetlands - methodological aspects. Hydrobiologia 269:285-296

Waide RB, Willig MR, Steiner CF, Mittelbach G, Gough L, Dodson SI, Juday GP, Parmenter R (1999) The relationship between productivity and species richness. Annu Rev Ecol Syst 30:257-300

Wardle DA, Bonner KI, Barker GM (2000) Stability of ecosystem properties in response to above-ground functional group richness and composition. Oikos 89:11-23

Webb P, Wooldridge T, Schlacher T (1997) Osmoregulation and spatial distribution in four species of mysid shrimps. Comp Biochem Physiol A 117:427-431

Woodward RT, Wui YS (2001) The economic value of wetland services: a meta-analysis. Ecol Econ 37:257-270

Worm B, Lotze HK, Hillebrand H, Sommer U (2002) Consumer versus resource control of species diversity and ecosystem functioning. Nature 417:848-851

Submitted: January 28, 2005; Accepted: October 21, 2005

Proofs received from author(s): March 9, 2006 